\title{
Tanggung Jawab Sosial dan Lingkungan Perusahaan Penanaman Modal
}

\author{
Ahmad Fauzi \\ Fakultas Hukum Universitas Muhammadiyah Sumatera Utara \\ Jl. Kapten Mukhtar Basri No. 3 Medan 20238 \\ Telp:(061)6622400. Fax (061) 6623474.6631003 \\ Email: ahmadfauzi@umsu.ac.id
}

Naskah Diterima: 28-02-2020, Direvisi: 29-06-2020, Disetujui: 06-07-2020, Diterbitkan: 07-07-2020 DDI: https://dai.org//0.30596/dll.v5i2.4369

\begin{abstract}
Abstrak
Tanggung jawab sosial dan lingkungan perusahaan sebagai sebuah komitmen perusahaan terhadap pembangunan ekonomi berkelanjutan dalam upaya meningkatkan kualitas kehidupan dan lingkungan. Sehingga komitmen ini tidak hanya kewajiban menganggarkan dana, hal yang lebih penting bagaimana agar perusahaan rnenjadikan kepedulian terhadap lingkungan dan masyarakat sebagai bagian dari rencana strategis setiap aktivitas perusahaan. Tanggung jawab sosial dan lingkung perusahaan diharapkan tidak sekedar mengacu pada input anggaran financial yang disediakan, namun meliputi kepatutan dan kewajaran terhadap aktivitas perusahaan secara menyeluruh sebagai realisasi kepeduliannya terhadap lingkungan dan masyarakat. Metode penelitian deskriptif analitis yang dilengkapi dengan studi kepustakaan dan komparatif, serta pendekatan yuridis normatif. Hasil penelitian menunjukkan bahwa Itanggung jawab sosial dan lingkungan perusahaan (corporate social responsibility) harus dilakukan secara kemitraan para stakeholders yang diikuti transparansi dan akuntabintas dan semua pihak.
\end{abstract}

\section{Kata Kunci: Tanggung jawab, Perusahaan, Penanaman Modal.}

\section{Abstract}

Corporate social responsibility is a corporate commitment to sustainable economic development in an effort to improve the quality of life and the environment. So that this commitment is not only the obligation to budget funds, but also how to care for the environment and the community as part of the strategic plan of each company's activities. Corporate social responsibility and environment are expected to not merely refer to the financial budget inputs provided, but include the appropriateness and fairness of the company's overall activities as a realization of its concern for the environment and society. This writing used descriptive analytical research methods complemented by literature and comparative studies, as well as normative juridical approaches. The results showed that corporate social and environmental responsibility (corporate social responsibility) must be carried out in partnership with the stakeholders followed by transparency and accountability and all parties.

Keywords: Responsibility, Company, Investment. 


\section{PENDAHULUAN}

Prinsip yang dijadikan landasan dalam penyusunan pembangunan ekonomi tersebut tidak dapat dilepaskan dari prinsip yang terkandung dalam Undang-Undang Dasar 1945 yaitu prinsip kebersamaan, efisiensi berkeadilan, berkelanjutan, berwawasan lingkungan, kemandirian, serta dengan menjaga keseimbangan, kemajuan dan kesatuan ekonomi nasional. Dalam pembangunan hukum, telah digariskan suatu pendekatan sistem hukum nasional yang mengandung prinsip-prinsip konstitusi tersebut. Pembangunan hukum memiliki peranan yang sangat penting dalam mendukung pembangunan ekonomi.

Pembangunan ekonomi Indonesia dilaksanakan secara terencana diupayakan untuk meningkatkan investasi (Rahmal, 2005) asing melalui perbaikan prosedur perizinan investasi, perbaikan infra struktur, serta penegakan hukum. Berkembangnya ekonomi suatu negara juga tidak terlepas dari peran korporasi salah satunya perusahaan penanaman modal dalam menjamin kesejahteraan masyarakat yang berada di sekitar perusahaannya.

Konsekuensi logis dari suatu negara yang sedang berkembang, memandang pentingnya modal dan teknologi asing dalam rangka memacu percepatan (akselerasi) pertumbuhan ekonomi, demikian juga halnya Indonesia, namun secara bersamaan harus dihindarkan dominasi asing atas perekonomian Indonesia. Oleh karena itu pembangunan di bidang ekonomi harus selaras dengan pembangunan di bidang-bidang lain, terutama pembangunan bidang hukum, karena keduanya mempunyai keterkaitan yang sangat erat.

Faktor penting yang diperlukan dalam pembangunan bidang ekonomi adalah permodalan. Salah satu langkah mengatasi kebutuhan akan permodalan, pemerintah Indonesia telah mengadakan pendekatan dalam kebijakan di bidang ekonomi, antara lain dengan mengundang penanaman modal asing. Bahwa peran hukum juga sentralistik untuk pembangunan ekonomi terkhusus manfaat CSR yang mengandung manfaat ekonomi bagi masyarakat setempat berkaitan dengan perusahaan penanaman modal. Guna mendorong dan membina penanaman modal asing di Indonesia maka sejak pada tanggal 16 Februari 1966 pemerintah Indonesia telah ikut serta menandatangani suatu konvensi Internasional (convention on the settlement of investement disputes between states and national of other state), yang kemudian diratifikasi dengan Undang-Undang Nomor 1 Tahun 1967 Tentang Penanaman Modal Asing (UUPA), jo Undangundang Nomor 6 Tahun 1967 Tentang Penanaman Modal Dalam Negeri serta Undang-Undang Nomor 11 Tahun 1970 TentangPerubahan dan Tambahan Undang-Undang Nomor. 1 Tahun 1967 Tentang Penanaman Modal Asing dan Undang-Undang Nomor 12 Tahun 1970 TentangPerubahan dan Tambahan Undang-Undang Nomor 1 Tahun 1967 Tentang Penanaman Modal, sampai akhirnya ditetapkan dengan Undang-Undang Nomor 25 Tahun 2007 Tentang Penanaman Modal, Undang-Undang Nomor 40 Tahun 2007 tentang Perseroan Terbatas serta Peraturan Pemerintah Nomor 47 Tahun 2012 tentang Tanggung Jawab Sosial Dan Lingkungan Perseroan Terbatas.

Di samping itu pemerintah mewajibkan penanaman modal asing memberikan kesempatan kepada modal nasional untuk ikut berpartisipasi setelah jangka waktu tertertentu. Kontradiksi ini adalah suatu yang logis dari pendirian negara-negara yang sedang berkembang yang memandang pentingnya modal dan teknologi asing untuk mewujudkan pertumbuhan ekonomi di negara-negara 
berkembang khususnya Indonesia, namun dominasi asing terhadap perekonomian negara berkembang diusahakan jangan di dominasi secara keseluruhan.

Menyadari bahwa penanaman modal baik modal asing maupun modal dalam negeri adalah merupakan faktor yang menentukan berhasilnya pembangunan di Indonesia. Untuk itu upaya pemerintah mengundang investor asing agar menanamkan modalnya di Indonesia, dilandasi oleh bukti bahwa peran investor asing terhadap perekonomian, Indonesia ternyata sangat signifikan dalam memacu percepatan roda pembangunan (ekonomi) di Indonesia, setidak ini terbukti ketika para investor asing, meninggalkan Indonesia akibat ketidakpastian politik, hukum, keamanan dan perekonomian di Indonesia.

Awalnya penanaman modal khususnya modal asing terbuka untuk semua bidang usaha kecuali bidang-bidang tertentu yang menyangkut kepentingan negara dan hajat hidup orang banyak, seperti pelabuhan, tenaga listrik, telekomunikasi, pelayaran, air minum minum, kereta api, pembangkit tenaga atom dan media massa. Bidang-bidang tersebut tidak dapat sepenuhnya dikuasai oleh modal asing dengan pengecualian bahwa penanaman modal asing hanya dapat dilakukan dengan bekerjasama dengan pemerintah Indonesia atau dengan perusahaan-perusahaan negara. Suatu ketentuan yang cukup penting untuk mencegah dominasi modal asing adalah adanya kewajiban dari modal asing untuk memberikan kesempatan partisipasi bagi modal nasional secara efektif setelah jangka waktu tertentu menurut imbangan yang ditetapkan oleh pemerintah.

Melihat realita masyarakat pada era globalisasi ini, hendaknya modal asing diberikan kesempatan untuk berkompetisi dengan modal nasional dalam memberikan pelayanan kepada masyarakat, sebab dengan kompetisi tersebut tentunya membawa dampak positif bagi masyarakat dengan berbagai keuntungan selain banyaknya pilihan yang tersedia. Urgensinya bahwa melihat kenyataan keberadaan modal nasional baik oleh pemerintah maupun swasta tidak begitu besar manfaatnya bagi hajat hidup rakyat Indonesia karena pada umumnya hanya mementingkan keuntungan perusahaan semata. Sebaliknya pelayanan yang diberikan oleh modal asing melalui penanaman modal asing (PMA) dirasakan kurang relatif baik.

Penanaman modal di era pasar bebas dimana dunia seolah menjadi tidak terbatas telah menempatkan semua penduduk dunia dalam satu komunitas global, di mana keadaan dunia semakin tidak mempunyai batas. Perkembangan dunia era milenium II ditandai dengan semakin pesatnya loncatan kemajuan bidang ilmu pengetahuan dan teknologi (IPTEK). Perkembangan ini terasa semakin multi dimensi ketika dihadapkan pada tuntutan dan kebutuhan manusia yang demikian beragam.

Kompleksitas ini semakin bertambah manakala dihubungkan dengan pola hubungan bisnis yang terjalin di masyarakat moderen. Implikasi ini telah mengubah wajah perdagangan dan perekonomian dunia menjadi bentuk bisnis dalam komunitas global. Urgensi penanaman modal asing berkaitan dengan kebutuhan modal pembangunan suatu negara. Masuknya investor-investor asing pada akhirnya diarahkan untuk menunjang ekselerasi pembangunan nasional. Penanaman modal asing tersebut dimanfaatkan dalam rangka mengisi kekurangan permodalan dan kemampuan nasional, sehingga perannya sebagai pelengkap modal yang telah tersedia. 
Indonesia walau masih banyak kritik pedas dari luar juga telah berusaha untuk memberikan iming-iming kepada investor asing, misalnya dengan menerbitkan paket deregulasi yang antara lain telah mengurangi daftar negatif investasi, kemudian penurunan investasi sampai pada penurunan tarif dan sebagainya. Di samping berbagai alternatif di atas, juga telah dibuat UndangUndang Nomor 25 Tahun 2007 Tentang Penanaman Modal (selanjutnya disenut UUPM), dimana UUPM ini telah memberikan berbagai kemudahan atau fasilitas yang ada. Undang-Undang Nomor 25 Tahun 2007 Tentang Penanaman Modal, juga menyatakan bahwa perusahaan yang beroperasi dalam rangka penanaman modal di Indonesia harus berbentuk Perseroan Terbatas berdasarkan hukum Indonesia dan berkedudukan di dalam wilayah negara Republik Indonesia. Cara melakukan penanaman modal bentuk Perseroan Terbatas dapat dilakukan dengan: Pertama, mengambil bagian saham (Amanat, 1997, h. 41) pada saat pendirian Perseroan Terbatas, Kedua, membeli saham, Ketiga, melakukan cara lain sesuai dengan ketentuan peraturan perudanganudangan.Tujuan mengundang penanaman modal terutama asing, pada hakikatnya untuk alih teknologi. Alih teknologi dapat terjadi melalui sarana pendidikan dan latihan, bantuan teknik, mempekerjakan ahli asing. Menurut Sunaryati Hartono, ahli teknologi merupakan suatu proses yang terdiri dari beberapa tahap yaitu imitasi, adaptasi dan asimilasi untuk kemudian melahirkan inovasi penemuan baru (Hartono, 1974, h. 27).

Alih teknologi yang di peroleh dari Penanaman modal asing pada hakikat membangunan industrialisasi negara. Oleh karena pembangunan industrialisasi di mana pun, tak terkecuali di wilayah tertinggal sesungguhnya selalu akan melahirkan sejumlah dilema. Di satu sisi industrialisasi diharapkan dapat menjadi jalan keluar dan pintu terobosan untuk mempercepat upaya penanggulangan kemiskinan dan keterbelakangan. Tetapi, di sisi yang lain industrialisasi dan investasi berbagai kekuatan komersial ternyata seringkali malah melahirkan proses marginalisasi, kerusakan ekologis dan tidak berkesesuaian dengan kebutuhan masyarakat lokal. Peranan perusahaan dalam menjaga lingkungan juga kini telah diwajibkan oleh Undang-Undang Nomor 40 Tahun 2007 tentang Perseroan Terbatas. Alih teknologi jika dikaitkan dengan CSR maka perlu diawasi agar perusahaan benar-benar melaksanakan tanggungjawabnya untuk menjaga kelestarian lingkungan agar tidak mengganggu kesehatan masyarakat disekitar perusahaan itu beraktivitas.

Di dalam pasal 74 ayat (1) Undang-Undang Nomor 40 Tahun 2007 tentang Perseroan Terbatas dinyatakan bahwa setiap perseroan yang menjalankan kegiatan usahanya di bidang dan/atau berkaitan dengan sumber daya alam wajib melaksanakan Tanggung Jawab Sosial dan Lingkungan. Sejalan dengan ketentuan dalam pasal 74 Undang-Undang Nomor 40 Tahun 2007 tentang Perseroan Terbatas, penjelasan atas pasal tersebut memberikan batasan bahwa perseroan yang menjalankan kegiatan usahanya di bidang sumber daya alam adalah perseroan yang kegiatan usahanya mengelola dan memanfaatkan sumber daya alam. Sedangkan perseroan yang menjalankan kegiatan usahanya yang berkaitan dengan sumber daya alam adalah perseroan yang tidak mengelola dan tidak memanfaatkan sumber daya alam, tetapi kegiatan usahanya berdampak pada fungsi kemampuan sumber daya alam. Pasal 74 ayat (2) Undang-Undang Nomor 40 Tahun 2007 tentang Perseroan Terbatas lebih lanjut menyebutkan bahwa Tanggung Jawab Sosial dan 
Lingkungan merupakan kewajiban perseroan yang dianggarkan dan diperhitungkan sebagai biaya perseroan yang pelaksanaannya dilakukan dengan memperhatikan kepatutan dan kewajaran. Lebih lanjut dijelaskan bahwaBiaya ini harus dicantumkan dalam laporan tahunan perusahaan seperti dapat dilihat dari pasal 66 ayat (2) Undang-Undang Nomor 40 Tahun 2007 tentang Perseroan Terbatas yang menyatakan bahwa Laporan Tahunan yang disampaikan oleh Direksi harus turut menyertakan laporan pelaksanaan Tanggung Jawab Sosial dan Lingkungan. Dengan kata lain CSR disclosure juga telah menjadi kewajiban hukum yang bertali temali dengan Undang-Undang Nomor 25 Tahun 2007 Tentang Penanaman Modal.

Kemudian dijelaskan dalam Peraturan Pemerintah Nomor 47 Tahun 2012 tentang Tanggung Jawab Sosial Dan Lingkungan Perseroan Terbatas Pasal 5 angka (2) bahwa biaya tanggung jawab sosial dan lingkungan dilaksanakan dengan biaya perseroan. Jika tidak melaksanakan Tanggung Jawab Sosial Dan Lingkungan Perseroan Terbatas dikenai sanksi sesusai dengan ketenntuan peraturan perundang-undangan (Pasal 7).

Berdasarkan temuan-temuan di atas dapat dilihat bahwa telah terjadi suatu pergeseran pandangan atas CSR, yang tidak lagi melihatnya merugikan perusahaan, tapi sebaliknya justru dapat menguntungkan perusahaan. Hal ini mungkin dapat turut disebabkan oleh berubahnya kriteria kesuksesan. Pandangan umum melihat bahwa kriteria kesuksesan tertumpu pada margin keuntungan dan kenaikan nilai saham semata-mata. Tetapi kini kriteria ini telah berkembang, yaitu bagaimana dampak yang dihasilkan oleh suatu perusahaan terhadap kualitas kehidupan masyarakat (Kotler, Philip dan Lee, Nancy, 2005, h. 7).

Tanggung jawab perusahaan yang tinggi sangat diperlukan karena dengan mewajibkan perusahaan menyisihkan sebagian keuntungannya untuk usaha sosial kemasyarakatan diharapkan dapat ikut memberdayakan masyakarat secara sosial dan ekonomi. Namun pewajiban dalam suatu Undang-undang dapat memunculkan multi tafsir yang menyebabkan tujuan menjadi tidak tercapai. Di antara permasalahan yang harus ditegaskan adalah perusahaan apa saja yang wajib melaksanakan tanggung jawab sosial, sanksi apa saja yang mungkin dapat dikenakan apabila tidak melaksanakan kewajiban tersebut, sistem pelaporan dan standar kegiatan yang termasuk dalam kategori kegiatan tanggung jawab social (http://www.madani-ri.com/ diakses tertanggal 23 Januari 2020).

\section{METODE PENELITIAN}

Melalui metode penelitian deskriptif analitis yang dilengkapi dengan studi kepustakaan dan komparatif, serta pendekatan yuridis normatif penelitian ini berhasil menunjukkan bahwa ada pergeseran konsep tanggungjawab sosial perusahaan dari kedermawanan, bergeser menjadi kewajiban untuk berbagi keuntungan dengan masyarakat, menjaga lingkungan hidup, mernberi lapangan kerja, mengembangkan usaha kecil dan ekonomi rakyat pada umumnya. Tanggung jawab sosial dan lingkung perusahaan berhubungan erat dengan Pembangunan berkelanjutan dimana perusahaan harus lebih memberdayakan komunitas masyarakat sekitar dalam perencanaan tanggung jawab sosial dan lingkung perusahaan tersebut. Namun keputusan akhir tetap berada pada perusahaan dalam mengakomodasi kepentingan dan kebutuhan masyarakat yang 
beragam, sehingga akibat tanggung jawab sosial dan lingkungan perusahaan untuk peningkatan kesejahteraan rakyat.dan akhirnya kosep tanggung jawab sosial dan lingkungan perusahan untuk meningkatkan penanaman modal di Indonesia.

\section{PEMBAHASAN DAN ANALISIS}

\section{Kebijakan Penanaman Modal}

Negara Indonesia adalah negara hukum yang menjunjung tinggi hukum sehingga segala pelanggaran dan kejahatan yang dilakukan akan ditindak dan diberi sanksi baik sanksi pidana maupun sanksi administrasi sesuai dengan perbuatan yang dilakukan (Faisal, 2018, h. 149). Presiden Republik Indonesia (Susilo Bambang Yudhoyono) telah mengesahkan Undang-Undang Nomor 25 Tahun 2007 tentang Penanaman Modal (K.Harjono, Dhanisvira, 2007, h. 17). Kebijakan yang telah di keluarkan pemerintah dengan melahirkan dan mengesahakan.

Undang-Undang Nomor 25 Tahun 2007 tentang Penanaman Modal merupakan bukti pemerintah untuk menarik investsi ke dalam negeri sekaligus menjamin kepastian hukum bagi investor yang mau menanakan modalnya ke negeri ini. Perkembangan peekonomian dunia pada saat mengalamin krisis ekonomi dunia, membuat Indonesia sulit menarik investor untuk beinvestasi di sini. Walaupun ada beberapa andalan yang masih menarik investor seperti pasar dalam negeri masih cukup aktif dan berpeluang untuk berkembang pesat. Sumber daya alam masih cukup besar dan beranekaragam, tidak bisa lagi diandalkan sepenuhnya.

Selain itu ada beberapa faktor yang menyebabkan keenggan investor untuk berinvestasi di Indonesia, diantaranya sulit memrealisasi proyek-proyek investasinya terutama dalam hal: (Anoraga,1995, h. 83-84).

1. Tidak mudahnya memperoleh dukungan pembiayaan

2. Sulit mendapatkan lahan usaha sesuai dengan kebutuhan dan dalam waktu yang cepat

3. Sarana dan prasarana yang masih belum memadai terutama di luar Pulau Jawa

4. Kurangnya tenaga kerja yang sudah terampil dan yang siap pakai serta tingginya upah pekerjaan.

5. Sulit mencari mitra usaha yang tangguh/bonafid dan dipercaya

6. Lamanya proses pengurusan perizinan, terutama di daerah.

Berapa negara yang mempunyai kepentingan dalam menarik investor, seperti RRC,Vietnam, India, beberapa negara ASEAN (Malaysia, Thailand, Filipina) dan negara-negara Amerika Latin juga memiliki berbagai keunggulan bahkan melebih Indonesia seperti tenaga kerja yang lebih murah di India, Singapura, Vientnam, RRC serta proses perizinan yang lebih mudah dan cepat (Anoraga, 1995, h. 151).

Bahkan semakin diperlemah dengan ada kenyataan pasar dunia menjadi terbuka (pasar bebas) dan semakin majunya perundingan-perundingan perdagangan internasional serta gencara untuk mencabut beberapa hambatan-hambatan yang memperlambat proses perizinan investasi Indonesia lebih dititikberatkan kapada efisiensi. Hal ini upaya Indonesia untuk meningkatkan investasi yang mempunyai daya saing lebih dari keadaan negara-negara pesaing utama Indonesia. 
Hal yang utama pemerintah Indonesia harus bisa memperbaikai diri terhadap unsur-unsur penghambat investasi tersebut diatas. agar mampu menyiapkan iklim investasi yang kodusif.Sehingga para investor menjadi tertarik menanamkan modalnya di Indonesia dan bukan membuat para pengusaha asing justru lari meninggalkan Indonesia, sebagaimana sekian banyak yang terjadi selama ini. Sebagai negara berkembang yang sedang mebangun, Indonesia membutuhkan dana yang cukup besar untuk pembangunan. Disamping usaha mobilisasi dana dari luar negeri, dana dari investasi dari luar negeri diluar pinjaman pemerintah juga terus diupayakan. Dengan kondisis perekonomian di dalam negeri yang belum sepenuhnya kondunsif seperti saat sekarang ini, banyak investor asing yang masih enggan untuk menanamkan modalnya di Indonesia.

Di dalam upaya menarik minat investor asing menanamkan modalnya di Indonesia, pemerintah terus meningkatkan kegiatan promosi baik melalui pengiriman utusan keluar negeri maupun peningkatan kerjasama antar pihak swasta nasional dan asing. Karena saat in banyak investor dari luar negeri yang berhati-hati dan selektif untuk menanamkan modalnya atau untuk berinvestasi ke Indonesia. Hal ini sangat terkait dengan situasi keamanana dan ketertiban di dalam negeri belum sepenuhnya dianggap aman.

Aminuddin Ilmar dalam Zainuddin (2019) Membicarakan wewenang maka membicarakan bagaimana kedudukan wewenang pemerintahan terhadap penyelenggaraan pemerintahan tidak bisa dilepaskan kaitannya dengan penerapan asas legalitas dalam sebuah konsepsi Negara hukum yang demokratis atau Negara demokrasi yang berdasar atas hukum. Kebijakan dasar penanaman modal, bertujuan untuk mendorong terciptanya iklim usaha nasional yang kondusif bagi penanaman modal untuk penguatan daya saing perekonomian nasional serta mempercepat peningkatan penanaman modal. Tujuan penyelenggaraan penanaman modal, antara lain untuk:(Muhammad Lutfi melaluihttp://www.setneg.go.id di akses tertanggal 23 Januari 2020).

1. Menciptakan pertumbuhan ekonomi,

2. Menciptakan lapangan kerja,

3. Menciptakan pembangunan ekonomi berkelanjutan,

4. Menciptakan daya saing dunia usaha nasioanal,

5. Menciptakan kapasitas dan kemampuan teknologi nasional,

6. Mendorong pengembangan ekonomi kerakyatan,

7. Mengolah ekonomi potensial menjadi kekuatan ekonomi riil, dan

8. Menciptakan kesejahteraan masyarakat.

Pemerintah memberi perlakuan yang sama bagi penanaman modal dalam negeri dan penanaman modal asing dengan tetap memperhatikan kepentingan nasional dan Pemerintah juga menjamin kepastian hukum, kepastian berusaha, dan keamanan berusaha bagi penanam modal sejak proses pengurusan perizinan sampai dengan berakhirnya kegiatan penanaman modal sesuai dengan ketentuan peraturan perundang-undangan dan membuka kesempatan bagi perkembangan dan memberi perlindungan kepada usaha mikro, kecil, menengah dan koperasi (Lutfimelalui http://www.setneg.go.id, di akses tertanggal 23 Januari 2020).

Pemerintah memberikan perlakuan yang sama kepada semua penanam modal yang berasal dari negara manapun untuk melakukan kegiatan penanaman modal di Indonesia sesuai dengan 
ketentuan-ketentuan perundang-undangan. Dan perlakuan sama ini tidak berlaku bagi penanam modal dari suatu negara yang memperoleh hak istimewa berdasarkan perjanjian dengan Indonesia

Perusahaan penanam modal dalam memenuhi kebutuhan tenaga kerja harus mengutamakan tenaga kerja Warga Negara Indonesia. Sementara itu perusahaan penanaman modal berhak menggunakan tenaga ahli warga negara asing untuk jabatan dan keahlian tertentu sesuai dengan peraturan perundang-undangan. Selanjutnya perusahaan penanaman modal wajib meningkatkan kompetensi tenaga kerja Indonesia melalui pelatihan kerja sesuai dengan peraturan perundangundangan.

Pemerintah telah mengembangkan berbagai paket kebijakan; antara laian dengan mengesahkan dan memberlakukan Undang-Undang Nomor 25 Tahun 2007 tentang Penanaman Modal yang merupakan bukti adanya jaminan kepastian hukum bagi investor untuk berinvestasi di Indonesia. Undang-Undang Nomor 25 Tahun 2007 mengamanatkan bahwa perusahaan penanaman modal yang akan melakukan kegiatan usaha wajib memperoleh izin sesuai dengan ketentuan peraturan perundang-undangan dari instansi yang memiliki kewenangan dan izin tersebut diperoleh melalui pelayanan satu pintu. Pelayanan terpadu satu pintu tersebut bertujuan membantu penanam modal dalam memperoleh kemudahan pelayanan, fasilitas fiskal dan informasi. Mengenai penanaman modal dan pelayanan terpadu satu pintu dilakukan oleh lembaga atau instansi seperti Badan Koordinasi Penanaman Modal (selanjutnya disebut BKPM) di tingkat Pusat atau Badan Koordinasi Penanaman Modal Daerah(selanjutnya disebut BKPMD) atau sejenisnya di tingkat daerah. Dengan demikian, dalam waktu yang tidak terlalu lama, perizinan investasi di seluruh Indonesia akan dilaksanakan melalui pelayanan terpadu Satu Pintu.

Pasal 25 Undang-Undang Nomor 25 Tahun 2007 Tentang Penanaman Modal menyebutkan bahwa perusahaan penanaman modal yang akan melakukan kegiatan usaha wajib memperoleh izin sesuai dengan ketentuan perundang-undangan dari instansi yang memiliki kewenangan, kecuali ditentukan lain dalam undang-undang, izin diperoleh melalui Pelayanan Terpadu Satu Pintu. Di dalam Pasal 26 Undang-Undang Nomor 25 Tahun 2007 Tentang Penanaman Modal dinyatakan:

1. Pelayanan terpadu satu pintu bertujuan membantu penanam modal dalam memperoleh kemudahan pelayanan, fasilitas fiskal, dan informasi mengenai penanaman modal.

2. Pelayanan terpadu satu pintu dilakukan oleh lembaga atau instansi yang berwenang di bidang penanaman modal yang mendapat pendelegasian atau pelimpahan wewenang dari lembaga atau instansi yang memiliki kewenangan perizinan dan non perizinan di tingkat pusat atau lembaga atau instansi yang berwenang mengeluarkan perizinan dan non perizinan di provinsi atau kabupaten/kota.

Selanjutnya Pasal 28 ayat (1) huruf j Undang-Undang Nomor 25 Tahun 2007 Tentang Penanaman Modal disebutkan bahwa Badan Koordinasi Penanaman Modal mempunyai tugas dan fungsi koordinasi dan melaksanakan pelayanan terpadu satu pintu. Pelayanan Terpadu Satu Pintu dimaksudkan untuk mempermudah perizinan investasi di Indonesia yang selama ini dikenal biaya tinggi (high cost) karena banyaknya korupsi birokrasi atau pungutan liar. Oleh karena itu, UndangUndang Nomor 25 Tahun 2007 Tentang Penanaman Modal mencoba menghilangkan atau mencegah korupsi birokrasi dengan cara menerapkan pelayanan terpadu satu pintu. 
Peraturan Menteri Dalam Negeri Nomor 24 Tahun 2006 tentang Pedoman Penyelenggaraan Pelayanan Terpadu Satu Pintu mewajibkan kepada Bupati atau Walikota untuk melakukan penyederhanaan penyelenggaraan perizinan melalui pelayanan terpadu satu pintu. Penyederhanaan pelayanan tersebut meliputi pelayanan atas permohonan perizinan dan non perizinan, percepatan waktu proses penyelesaian, kepastian biaya pelayanan kejelasan prosedur pelayanan, mengurangi berkas kelengkapan permohonan perizinan, pembebasan biaya perizinan bagi usaha kecil, mikro dan menengah dan akses informasi bagi masyarakat.

Pelayanan Terpadu Satu Pintu juga diatur dalam Peraturan Pemerintah Nomor 38 Tahun 2007 tentang Pembagian Urusan Pemerintahan antara Pemerintah Pusat, Pemerintah Daerah Provinsi, dan Pemerintah Kabupaten/Kota. Sejak tahun 1999, Asia Foundation telah mengembangkan program penyederhanaan perizinan usaha di 55 kabupaten/kota dengan mendorong pembentukan sebuah instansi pelayanan terpadu untuk perizinan usaha, yang sekarang lebih dikenal dengan nama Pelayanan Terpadu Satu Pintu (selanjutnya di sebut PTSP). PTSP ini pada dasarnya adalah sebuah kantor yang mengkoordinasi dan mengkonsolidasi penerbitan izin, menyederhanakan proses perizinan serta mengurangi jumlah meja yang harus dilalui pelaku usaha. Walaupun pemerintah nasional sadar mengamanatkan pembentukan PTSP di seluruh Indonesia.

\section{Pengertian, Karakteristik dan Prinsip Tanggung Jawab Sosial dan Lingkungan Perusahaan}

Adanya revolusi industri telah menyebabkan masalah tanggung jawab perusahaan menjadi fokus yang tajam. Ini merefleksikan kekuatan industri baru untuk membentuk kembali hubungan yang sudah kuno. Feodal, klan, rumpun, atau sistem otoritas yang berlandaskan kekeluargaan dan teknologi memberi kekuasaan yang besar dan kekayaan pada "perusahaan". Tanah harus dibagibagi kembali dan kota-kota dibangun. Kekuatan mesin yang melebihi manusia meningkatkan masalah tanggung jawab dan moralitas (Canon, 1995, h. 2).

Salim HS dan Nurbani dalam Fajaruddin (2018) disebutkan bahwa istilah teori efektivitas hukum berasal dari terjemahan bahasa Inggris, yaitu effektiveness of the legal theory, bahasa Belanda disebut dengan effectiviteit van de juridische theorie, bahasa Jermannya, yaitu wirksamkeitt der rechtlichen theorie. Salim HS dan Erlies Septiana Nurbani, Penerapam Teori Hukum Pada Penelitian Tesis dan Disertasi (Fajaruddin, 2018, h. 207).

Di dalam artikel yang berjudul Dimensions of Corporate Social Performance, S. prakash Sethi memberikan penjelasan atas perilaku korporasi yang dikenal dengan social obligation, social responsibility, dan social responsiveness. Menurut Sethi, social obligation adalah perilaku korporasi yang didorong oleh kepentingan pasar dan pertimbangan-pertimbangan hukum. Dalam hal ini social obligation hanya menekankan pada aspek ekonomi dan hukum saja. Social responsibility merupakan perilaku korporasi yang tidak hanya menekankan pada aspek ekonomi dan hukum saja tetapi menyelaraskan social obligation dengan norma, nilai dan harapan kinerja yang dimiliki oleh lingkungan sosial. Social responsiveness merupakan perilaku korporasi yang secara responsif dapat mengadaptasi kepentingan sosial masyarakat. Social responsiveness merupakan tindakan antisipasi dan preventif. Dari pemaparan Sethi dapat disimpulkan bahwa social obligation bersifat wajib, social responsibility bersifat anjuran dan social responsiveness bersifat preventif. Dimensi-dimensi kinerja sosial (social performance) yang dipaparkan Sethi juga 
mirip dengan konsep lingkaran konsentris yang dipaparkan oleh Committee for Economic Development (CED)(Prayoga melalui http:/www.donhangga.com/ diakses tertanggal 11 Desember 2019).

Berdasarkan hal ini dibedakan secara jelas antara konsep kewajiban sosial (social obligation), tanggung jawab sosial (social responsibility), dan kepedulian sosial (social responsiveness).Dengan demikian berdasarkan hal diatas maka ada dua perspektif tentang CSR. Dua perspektif ini tidak muncul begitusaja, melainkan muncul dari dua cara pandang tentang "peran bisnis dalam masyarakat." Cara pandang pertama, "pandangan klasik" (classical view), yang didasarkan pada teori ekonomi neo-klasik, melihat peran bisnis dalam masyarakat murni sebagai pencarian keuntungan, yaitu keuntungan bagi para pemegang saham (shareholder). Cara pandang ini disebut juga sebagai "perspektif pemegang saham" (shareholder perspective). Sebaliknya, "pandangan pemangku kepentingan" (stakeholder view), yang didasarkan pada teori pemangku kepentingan, berkeyakinan bahwa perusahaan memiliki tanggung jawab sosial. Tanggung jawab sosial itu menuntut perusahaan untuk mempertimbangkan kepentingan semuapihak yang terkena pengaruh dari tindakannya. Hal ini yang sesuai dengan kondisi bangsa ini, bahkan SCR harus dijadikan tanggung jawab sosial dan lingkugan perusahaan yang di atur dalam perundang-undangan.

Corporate Social Responsibility (CSR) dalam perspektif filsafat moral di bidang ekonomi bisnis pada dasarnya adalah perwujudan perasaan etik perusahaan untuk mewujudkan sifat altruistic korporasi. Perasaan etik yang semula bersifat individual ini saat ini telah berkembang menjadi sebuah tuntutan global dalam dunia bisnis (Eggi Sudjana, Ruyanto, 1999, h. 132) Kemunculan CSR sebagai sebuah agenda global seiring dengan terjadinya perubahan cara pandang dunia usaha mengenai hubungan perusahaan dengan masyarakat dan lingkungan sekitar perusahaan. Perusahaan yang semula selalu diartikan sebagai institusi pengabdi kepada kepentingan pemegang saham, dituntut pula untuk memperhatikan kepentingan seluruh pemangku kepentingan yang ada di luar pemegang saham (shareholder), sebagaimana dikemukan Direktur Jenderal international labour organization (ILO) sebagai berikut:

"Kelompok bisnis yang ingin bertahan di era global, harus mengubah paradigma tanggung-jawabnya dari shareholders menjadi tanggung jawab sosial kepada stakeholders atau para pemilik saham secara luas, yakni pegawai, buruh, dan masyarakat di mana kegiatan bisnis itu berlangsung. Pertumbuhan global akan memberikan keuntungan lebih banyak, namun ekonomi global juga menuntut sejumlah kewajiban dari perusahaan-perusahaan multinasional. Hal ini membuat korporasi harus berjalan dengan satu seri standar sosial yang bisa diakui secara universal. Oleh karena itu, perusahaan khususnya perusahaan-perusahaan multinasional tidak bisa lagi mengabaikan tanggung jawab sosialnya kepada stakeholder kalau ingin bertahan dalam perdagangan bebas. Perusahaanperusahaan multinasional pun akan mengalami seleksi oleh sikapnya sendiri. Mereka akan berhadapan dengan kritik publik yang sangat menentukan keberlanjutan usahanya (Harian Kompas, 26 Juni 2000)".

Paling tidak ada 4 (empat) model atau pola CSR yang umumnya diterapkan oleh perusahaan di Indonesia yaitu: 


\section{Keterlibatan langsung}

Perusahaan menjalankan program CSR secara langsung dengan menyelenggarakan sendiri kegiatan sosial atau menyerahkan sumbangan ke masyarakat tanpa perantara.

2. Melalui Yayasan atau organisasi sosial perusahaan

Perusahaan mendirikan yayasan sendiri di bawah perusahaan atau grupnya. Model ini diadopsi dari negara maju.

3. Bermitra dengan pihak lain

Perusahaan menyelenggarakan CSR melalui kerjasama dengan lembaga sosial/organisasi nonpemerintah, instansi pemerintah, universitas atau media massa..

4. Mendukung atau bergabung dalam suatu konsorsium

Perusahaan turut mendirikan, menjadi anggota atau mendukung suatu lembaga sosial yang didirikan untuk tujuan sosial tertentu.

CSR dalam pengertian yang luas dipahami sebagai konsep yang lebih manusiawi dimana suatu organiasi dipandang sebagai agen moral. Oleh karena itu, dengan atau tanpa aturan hukum, sebuah organisasi bisnis, harus menjunjung tinggi moralitas. Dengang demikian kendati tidak ada aturan hukum atau etika masyarakat yang mengatur, tanggung jawab sosial dapat dilakukan dalam berbagai situasi dengan memperhatkan hasil terbaik atau yang paling sedikit merugikan stakeholder-nya (Nussahid, 2006, h. 5).

Berdasarkan pandang ini, sebuah organisasi bisnis dapat memutuskan tindak atau prilaku mana yang paling etis dalam situasi tertentu dengan menerapkan prinsip - prinsip moral. Salah satunya adalah penerapan prinsip "golden rule" yang mengajarkan seseorang atau satu pihak agar memperlakukan orang lain sama seperti mereka ingin diperlakukan. Para penganut konsep ini juga percaya bahwa tindakan tepat yang dilakukan oleh suatu perusahaan berdasarkan prinsip moral dengan sendirinya akan memberikan manfaat terbesar bagi masyarakat(Great R, 2001, h.15).

Karakteristik tanggungjawab sosial perusahaan yaitu terkait dengan adanya peran dengan menangani secara langsung membantu pemerintah melalui berbagai kegiatan sosial untuk menyantuni masyarakat disekitar perusahaan beraktivitas, mendukung berbagai lembaga sosial dan juga melaksanakan tanggungjawab lainnya yang wajar dalam hal pemenuhan kebutuhan masyarakat disekitarnya termasuk juga bertanggungjawab terhadap lingkungan.

\section{Konsepsi Tanggung Jawab Sosial dan Lingkungan Perusahaan dalam Pembangunan di Indonesia dalam Mencapai Tujuan Negara Kesejahteraan.}

Konsep dasar CSR adalah pemberdayaan masyarakat setempat yang notabene miskin agar terbebas dari kemiskinan. Selain pemberdayaan masyarakat dan sisi perusahaan, jelas agar operasional berjalan lancar tanpa gangguan. Jika hubungan antara perusahaan dan masyarakat tidak mesra, bisa dipastikait ada inasalali. Pelaksanaan program CSR behim sepenuhaya diterima oleh masyarakat, Itu sebabnya oleh minimnya perhatian perusahaan terhadap pelaksanaan CSR (Untung, 2008, h. 3).

Kontribusi CSR adalah kontribusi berkesinambungan terhadap pembangunan ekonomi berkelanjutan. yaitu bekerjasama dengan karyawan keluarga mereka, komunitas lokal, dan masyarakat luas untuk memperbaiki kualitas hidup dengan cara-cara yang dapat diterima oleh 
bisnis dan juga pembangunan itu sendiri adalah nilai dasar CSR. Kemiskinan yang sudah menggelobal saat ini adalah masalah sosial yang menjadi target seluruh negara di dunia untuk ditekan, bahkan dihapuskan dan tentunya dalam impleinentasi CSR kontemporer yang dilakukan dunia usaha. dan sudah seharusnya dalam usahanya menyadari posisi mereka bagian dari masyarakat(Untung, 2008, h. 5).

Di abad informasi dan teknologi serta adanya desakan globalisasi, maka tuntutan terhadap perusahaan untuk menjalankan CSR akan semakin besar. Tidak menutup kemungkinan bahwa CSR menjadi kewajiban baru standar bisnis yang harus dipenuhi seperti layaknya standar ISO. dalam ISO 26000 on Social Responsibility, telahditentukan bahwa dunia usaha menjadi semakin jelas akan pentingnya program CSR dijalankan oleh perusahaan apabila menginginkan berkelanjutan dari perusahaan tersebut.(Thimotius Lesmana, "Program Corporate Social Responsibility yang Berkelanjutan", http://wordpress.com/, diakses tertanggal 1 Januari 2020)

Sejumlah besar penelitian telah membuktikan kinerja sosial dan kinerja finansial perusahaan sungguh berkorelasi positif. Karenanya perdebatan mengenai keuntungan menjalankan CSRsesungguhnya dapat dianggap sudah berakhir. Namun beberapa kajian termasuk oleh ekonom terkemuka Michael Porter menunjukan adanya korelasi positif antara profit dan CSR, atau tujuan financial dan tujuan sosial perusahaan. Perusahaan yang mencatat laba tertinggi adalah para pionir dalam CSR.

Untuk berjalan baik, konsep corporate social responsibility harusmelibatkan tanggung jawab kemitraan antara pemerintah, lembaga sumberdaya masyarakat, juga masyarakat setempat (lokal). Kemitraan ini merupakan tanggung jawab bersama secara sosial antar stakeholders (K. Bertens, 2000, h. 162-165). Tanggung jawab sosial perusahaan lebih mengarah pada bagaimana suatu biaya materi yang dikemas dan diterapkan pada masyarakat dapat memperoleh keuntungan sosial dengan memberikan akses yang seluas-luasnya kepada masyarakat di luar perusahaan maupun di dalam perusahaan(Ernawan, 2000, h. 110).

Konsep dasar tanggung jawab sosial perusahaan adalah kesadaran bahwa terdapat hubungan timbal balik yang saling menguntungkan antara perusahaan dengan komunitas yang berada dalam lingkungan sekitarnya. Komunitas lokal mengharapkan perusahaan bersedia membantu dalam menghadapi masalah mereka. Sebaliknya pihak perusahaan mengharapkan mereka diperlakukan secara adil dan cara pandang yang suportif.

Hubungan-hubungan antar stakeholders diumpamakan sebagai aliran darah dalam organisasi. Seperti halnya sebuah entitas yang berada dalam hubungan simbolik pada sebuah lingkungan, seperti itulah yang dilakukan oleh perusahaan. Hubungan stakeholders menyediakan energi, informasi, dan sumber daya yang penting bagi kehidupan. Dalam hubungan ini perusahaan menciptakan modal sosial, modal intelektual, modal lingkungan dan modal fmansial dan keseluruhannya adalah upaya jangka panjang yang berkelanjutan (sustainability).

Penanam modal baik dalam maupun asing tidak dibenarkan hanya mencapai keuntungan dengan mengorbankan kepentingan-kepentngan pihak lain yang terkai dan harus tunduk dan mentaati ketentuan corporate social responsibility sebagai kewajiban hukum jika ingin menanamkan modalnya di Indonesia. Komitmen bersama untuk mewujudkan pembangunan 
berkelanjutan dan menciptakan iklim investasi bagi penanam modal untuk mewujudkan kesejahteraan masyarakat dapat tercapai melalui pelaksanaan corporate social responsibility. Corporate social responsibility (CSR) dalam konteks penanaman modal harus dimaknai sebagai instrumen untuk mengurangi praktek bisnis yang tidak etis. bagi pelaku usaha asing. Kegiatan sosial kemasyarakatan yang dilakukan secara sukarela itu, sudah biasa dilakukan oleh perusahaan-perusahaan multinasional ratusan tahun lalu.

Fuke dalam Hanifah (2020) menyebutkan bahwa Tujuan bernegara bangsa Indonesia ditemukan pada alinea keempat pembukaan UUD 1945 yakni tidak hanya melindungi warga negara tetapi juga mewujudkan kesejahteraan umum (public welfare), tujuan bernegara seperti ini disebut juga dengan negara hukum kesejahteraan (walfare state). Tanggung jawab negara itu dimaksudkan untuk menjamin hak-hak warga negara atas kehidupan yang layak sebagai manusia, dikemukakan oleh Toshiro Fuke sebagai berikut"The state now assuming the general mandate to secure for citizen their individual right to a life worthy of a human being.

Bahwa dengan adanya ketentuan CSR sebagai sebuah kewajiban dapat merubah pandangan maupun perilaku dari pelaku usaha, sehingga CSR tidak lagi dimaknai sekedar tuntutan moral, tetapi diyakinkan sebagai kewajiban perusahaan yang harus dilaksanakan. Kesadaran ini memberikan makna bahwa perusahaan bukan lagi sebagai entitas yang mementingkan diri sendiri, alienasi dan atau eksklusifitas dari lingkungan masyarakat, melainkan sebuah entitas usaha yang wajib melakukan adaptasi kultural dengan lingkungan sosial. Sehingga tidak berkelebihan jika ke depan CSR harus dimaknai bukan lagi hanya sekedar responsibility karena bersifat sukarela (voluntary), tetapi harus dilakukan sebagai wajib(mandatory) dalam makna liability karena disertai dengan sanksi (Ernawan, 2000)

Menyikapi kondisi yang ada tersebut, bahwa hukum sebagai produk kebijakan politik tidak selamanya merupakan suatu prasyaratan yang harus ada (conditio sine qua non) bagi tujuan yang hendak dicapai. Hal ini menunjukkan hukum mempunyai batas-batas kemampuan tertentu untuk mengakomodasi nilai-nilai yang tumbuh dan hidup dalam komunitas masyarakat, oleh karena itu Roscoe Pound menyatakan bahwa tugas hukum yang utama adalah "social engineering". Dalam doktrin ini dikatakan bahwa hukum harus dikembangkan sesuai dengan perubahan-perubahan nilai sosial. Untuk itu sebaiknya diadakan rumusan-rumusan kepentingan yang ada dalam masyarakat yaitu kepentingan pribadi, masyarakat dan umum (Ernawan, 2000).

Bahwa dengan demikian hukum bagi Roscoe Pound merupakan alat untuk membangun masyarakat (lawis a tool of social engineering). Sehingga hukum bukan saja berdasarkan pada akal, tetapi juga pengalaman. Akal diuji oleh pengalaman dan pengalaman yang dikembangkan oleh akal (Ernawan,2000). Undang-Undang Penanaman Modal ini adalah satu instrumen dalam penyelegaran perekonomian nasional, sedangkan didalam Pasal 33 Undang-Undang Dasar Tahun 1945 Republik Indonesia dinyatakan bahwa perekonomian nasional diselegarakan berdasarkan demokrasi ekonomi. Pembangunan nasional ini juga harus dilaksakan berdasarkan asas demokrasi dengan prinsip-prinsip kebersamaan, berkeadilan, berkelanjutan dan kemandirian dengan menjaga keseimbangan kemajuan dan kesatuan nasional. 
Pada kenyataanya apabila kepastian hukum dikaitkan dengan keadilan hukum, maka akan kerap kali tidak sejalan satu sama lain. Adapun hal ini dikarenakan di satu sisi tidak jarang kepastian hukum mengabaikan prinsip-prinsip keadilan hukum, sebaliknya tidak jarang pula keadilan hukum menga-baikan prinsip-prinsip kepastian hukum. Apabila dalam praktiknya terjadi pertentangan antara kepastian hukum dan keadilan hukum, maka keadilan hukum yang harus diutamakan.Alasannya adalah, bahwa keadilan hukum pada umumnya lahir dari hati nurani pemberi keadilan, sedangkan kepastian hukum lahir dari suatu yang konkrit. Kepastian hukum dapat diartikan sebagai sebuah keadaan yang pasti dan sesuai dengan ketetepan serta ketentuan dari tujuan dibentuknya suatu hukum. Kepastian hukum erat kaitannya dengan rasa aman dan nyaman, sebab hakikat dari kepastian hukum adalah menimbulkan kepastian terhadap segala sesuatu yang menyangkut keraguan, ketidakpastian dan rasa ketakutan yang bersifat manusiawi.Lebih jauh lagi, kajian tentang kepastian hukum erat kaitanya dengan kajian suatu keabsahan. Kaadaan yang pasti dinilai sebuah keadaan yang sah menurut peraturan peundang-undangan baik secara formil maupun materil (Ramadhani, 2017, h. 144).

Kegiatan penanaman modal itu dilakukan sebagai bagian mengatasi resesi yang ada untuk mempercepat pertumbuhan dan diprioritaskan keterkaitannya dengan ekonomi kerakyatan serta menciptakan pertumbuhan ekonomi dan teknologi yang berkaitan dengan kegiatan penanaman modal. Mocthtar Kusumaatmadja mengatakan bahwa hukum merupakan saran pembaharuan masyarakat didasarkan atas anggapan bahw adanya keteraturan atau ketertiban dalam usaha pembangunan atau pembaharuan itu merupakan suatu yang diinginkan atau bahkan dipandang (mutlak) perlu. Selanjutnya Mocthtar Kusumaatmadja mengatakan perubahan maupun ketertiban merupakan tujuan kembar dari masyarakat yang sedang membangun, maka hukum menjadi suatu yang tidak dapat diabaikan dalam proses pembangunan (Kusumaatmadja, 1976, h. 9). Pembinaan hukum harus mampu menampung kebutuhan hukum sesuai dengan keadaran hukum masyarakat Indonesia yang berkembang ke arah modernisasi (Hasan, 1999, h.33).

Konteks tanggung jawab sosial (CSR) dalam hal ini ada kewajiban bertanggung jawab atas perintah undang-undang, dan memperbaiki atau sebaliknya memberi ganti rugi atas kerusakan apa pun yang telah ditimbulkan. Tanggung jawab sosial berada pada ranah moral, sehingga posisinya tidak sama dengan hukum. Moral dalam tanggung ajwab social lebih mengarah pada tindakan lahiriah yang didasarkan sepenuhnya dari sikap batiniha, sikap inilah yang dikenal dengan "moralitas" yaitu sikap dan perbuatan baik yang betul-betul tanpa pamrih. Sedangkan tanggung jawab hokum lebih menekankan pada ksesuaian sikap lahiriah dengan aturan, meskipun tindakan tersebut secara obyektif tidak salah, barangkali baik dan sesuai dengan pandanan moral, hukum, dan nilai-nilai budaya masyarakat. Namun demikian kesesuaian saja tidak dapat dijadikan dasar untuk menarik suatu kesimpulan karena tidak tahu motivasi atau maksud yang mendasarinya.

Bila dikaitkan dengan teori tanggung jawab sosial dengan aktivitas perusahaan, maka dapat dikatakan bahwa tanggung jawab sosial lebih menekankan pada kepedulian perusahaan terhadap kepentingan stakeholders dalam arti luas dari pada kepedulian perusahaan terhadap kepentingan perusahaan belaka. Dengan demikian konsep tanggung jawab sosial lebih menekankan pada tanggung jawab perusahaan atas tindakan dan kegiatan usahanya yang berdampak pada orang- 
orang tertentu, masyarakat dan lingkungan di mana perusahaan- perusahaan melakukan aktivitas usahanya sedemikian rupa, sehingga tidak berdampak negatif pada pihak-pihak tertentu dalam masyarakat. Sedangkan secara positif hal ini mengandung makna bahwa perusahaan harus menjalankan kegiatannya sedemikian rupa, sehingga dapat mewujudkan masyarakat yang lebih baik dan sejahtera.

Kondisi Indonesia masih menghendaki adanya CSR sebagai suatu kewajiban hukum. Kesadara akan adanya CSR masih rendah, kondisinya yang terjadi adalah belum adanya kesadaran moral yang cukup dan bahkan seringkali terjadi suatu yang diatur saja masih ditabrak, apalagi kalau tidak diatur. Karena ketaatan orang terhadap hukum masih sangat rendah. CSR lahir dari desakan masyarakat atas perilaku perusahaan yang mengabaikan tanggung jawab sosial, seperti : perusakan lingkungan, eksploitasi sumber daya alam yang merusak alam, dan menindas buruh. Bahkan, kebanyakan perusahaan juga cenderung membuat jarak dengan masyarakat sekitar.

Jika situasi dan kondisi yang terjadi masih seperti tersebut di atas, maka hukum harus berperan. Tanggung jawab perusahaan yang semula adalah tanggung jawab non hukum (responsibility) akan berubah menjadi tanggung jawab hukum (liability). Otomatis perusahaan yang tidak memenuhi perundang-undangan dapat diberi sanksi. Kehadiran Undang-Undang Penanaman Modal Nomor 25 Tahun 2007 tentang Penanaman Modal diharapkan, mampu memberikan angin segar kepada investor dan memberikan iklim investasi yang menggairahkan. Kenyamanan dan ketertarikan investor asing terutama apabila terciptanya sebuah kepastian hukum dan jaminan adanya keselamatan dan kenyamanan terhadap modal yang ditanamkan. Secara garis besar tujuan dari dikeluarkannya Undang - Undang Penanaman Modal Nomor 25 Tahun 2007 tentang Penanaman Modal tentunya disamping memberikan kepastian hukum juga adanya transparansi dan tidak membeda-bedakan serta memberikan perlakuan yang sama kepada investor dalam dan luar negeri.

Adanya kepastian hukum dan jaminan kenyamanan serta keamanan terhadap investor, tentunya akan meningkatkan daya saing Indonesia di pasar global yang merosot sejak terjadinya krisis moneter. Berkaitan dengan hal tersebut, penanaman modal harus menjadi bagian dari penyelenggaraan perekonomian nasional dan ditempatkan sebagai upaya untuk menigkatkan pertumbuhan ekonomi nasional, menciptakan lapangan kerja, meningkatkan pembangunan ekonomi berkelanjutan, meningkatkan kapasitas dan kemampuan teknologi nasional, mendorong pembangunan ekonomi kerakyatan, serta mewujudkan kesejahteraan masyarakat dalam suatu sistem perekonomian yang berdaya saing.

\section{KESIMPULAN}

Impementasi tanggung jawab sosial dan lingkungan perusahaan (Corporate Social Responsibility) harus dilakukan secara Kemitraan para stakeholders yang diikuti transparansi dan akuntabintas dan semua pihak, pemerintah sebagai pembuat regulasi harus mampu menjembatani kepentingan dan memberi rasa keadilan bagi pelaku bisnis dan masyarakat yang mana regulasi dilaksanakan secara bijak. Pelaksanaan tanggungjawab sosial perusahaan seyogyanya disesuaikan dengan kemampuan masing-masing perusahaan dan kebutuhan masyarakat lokal. Idealnya terlebih dahulu dirumuskan bersama antara 3 pihak yang berkepentingan yakni pemerintah, dunia usaha 
seperti perusahaan swasta maupun yang dimiliki oleh negara/pemerintah, serta masyarakat setempat yang juga termasuk pihak berkepentingan. Kemudian dilaksanakan sendiri oleh masingmasing perusahaan, karena masing-masing perusahaan memiliki karakteristik lingkungan dan masyarakat yang berbeda antara satu dengan yang lain. Upaya perusahaan menerapkan tanggungjawab sosial perusahaan memerlukan sinergi dari pemerintah dan masyarakat. Pemerintah sebagai regulator diharapkan mampu berperan menumbuh kembangkan penerapan tanggungjawab sosial perusahaan di tanah air tanpa membebani perusahaan secara berlebihan. Peran masyarakat juga diperlukan dalam upaya perusahaan memperoleh rasa aman dan kelancaran dalam berusaha.

\section{SARAN}

Perlu dibentuk lembaga pengawasan oleh pemerintah dan masyarkat di kawasan di industri, yang dapat mengawasi secara langsung di lapangan dari setiap kegiatan tanggung jawab sosial dan lingkungan perusahaan(Corporate Social Responsibility)) yang dilakukan Perusahaan kepada masyarakat dalam impementasi program-progaram tanggung jawab sosial dan lingkungan perusahaan yang dilakukan perusahaan. Perlu dibuat deregulasi Pelaksana terhadap asas tanggung jawab sosial dan lingkungan perusahaan (Corporate Social Responsibility) terutama mengenai keseluruhan operasi dan dampaknya kepada pemangku kepentingan sehingga menjadi tolak ukur Impementasi tanggung jawab sosial dan lingkungan perusahaan. 


\section{DAFTAR PUSTAKA}

Amanat, Anisitus. (1997). Pembahasan Undang-Undang Perseroan Terbatas 1995 Dan Penerapannya Dalam Akta Notaris.Jakarta. Raja Grafindo Persada

Anoraga, Panji. (1995). Perusahaan Multinasional \& Penanaman Modal Asing. Jakarta: Pustaka Jaya.

Canon, Tom. (1995). Corporate Responsibility (Tanggung jawab Perusahaan), Jakarta: PT. Elex Media Komputindo.

Dhanisvira, K.Harjono. (2007). Hukum Penanaman Modal Tinjauan terhadap Pemberlakuan Undang-Undang Nomor 25 Tahun 2007 Tentang Penanaman Modal, Jakarta, Raja Gratindo Persada.

Erni R. Ernawan, Memmbangun Citra Bisnis Sebagai Profesi Luhur (Pustakan Filsafat), Kanisius, 2000.

Faisal. (2018). Akibat Hukum Ketiadaan Akta Ikrar Wakaf Atas Perwakafan Tanah. De Lega Lata Jurnal Ilmu Hukum Fakultas Hukum Umsu. 3 (2). 143-153. Https://Doi.Org/10.30596/Dll.V3i2.3154.

Fajaruddin. (2018). Efektivitas Undang-Undang Nomor 33 Tahun 2014 Tentang Jaminan Produk Halal Dalam Perlindungan Konsumen. De Lega Lata Jurnal Ilmu Hukum Fakultas Hukum UMSU. 204-216. 3 (2). Https://Doi.Org/10.30596/D1l.V3i2.3151.

Freeman R.E, Strategic Management: a Stakeholder Approach, Marchfield, MA, Pitman, 1984.

Hanifah, Ida. (2020).Peran Dan Tanggung Jawab Negara Dalam Perlindungan Hukum Tenaga Kerja Indonesia Yang Bermasalah Di Luar Negeri.De Lega Lata Jurnal Ilmu Hukum Fakultas Hukum Umsu.5 (1).10-23. Https://Doi.Org/10.30596/Dll.V5i1.3303.

Hartono, Sunarjati. (1974). Masalah-Masalah Dalam Joint Venture Modal Asing di Indonesia. Alumni.

Hasan,Djuhaendah. (1999). Lembaga Jaminan Kebendaan Bagi Tanah Dan Benda Lain Yang Melekat Pada Tanah Dalam Konsepsi Penerapan Asas Pemisahan Horisontal (Suatu Konsep Dalam Menyongsong Lahirnya Lembaga Hak Tanggungan), Penerbit Citra Aditya Bakti, Bandung.

Jones Great R, Oraganizational Theory, New Jersey,USA Prentice-Hall Inc, 2001.

K. Bertens, Pengantar Etika Bisnis (Seri Filsafat Atmajaya :21) Yogyakarta, Kanisius, 2000.

Kotler, Philip dan Lee, Nancy, Corporate Social Responsibility: Doing the Most Good for Your Company and Your Cause, (Hoboken: John Wiley and Sons, Inc,2005).

Kusumaatmadja,Mocthtar. (1976). Hukum Masyrakat dan Pembinaan Hukum Nasional. Bandung: Bina Cipta.

Lesmana, Thimotius. "Program Corporate Social Responsibility yang Berkelanjutan". Diakses tertanggal 1 Januari 2020. 
Lutfi, Muhammad. Strategi dan Kebijakan Investasi di Indonesia.http://www.setneg.go.id, di akses tertanggal 23 Januari 2010.

Nussahid, Fajar. Praktik Kedermawanan Sosial BUMN Analisis terhadap Model Kedermawanan PT Krakatau Stei, PT Pertaminan, PT Terkomunikasi Indonesia, Jurnal Galang, Vo, I No 2, Januari 2006.

Prayoga, Hangga Surya. “CSR: Sekilas Sejarah dan Konsep”, http://www.donhangga.com/, diakses pada tanggal 11 Desember 2019.

Rahmal, Ida Bagus. (2005). Kerangka Hukum Kebijakan Ivestasi Langsung di Indonesia, Jakarta: Ghalia Indonesia.

Ramadhani, Rahmat. (2017). Jaminan Kepastian Hukum Yang Terkandung Dalam Sertipikat Hak Atas Tanah. De Lega Lata Jurnal Ilmu Hukum Fakultas Hukum Umsu. 2 (1). 255-270.

Sudjana, Eggi., Ruyanto. (1999).Penegakan Hukum Lingkungan dalam Persepektif Etika Bisnis di Indonesia. Jakarta: Gramedia.

Sukarmi. Tanggung Jawab sosial Perusahaan (corporate social responsibility) dan Iklim Penanaman Modal Di Indonesia. www.legalitas.org, Diakses tanggal 22 Januari 2010.

Undang-Undang Nomor 25 Tahun 2007 Tentang Penanaman Modal.

Untung, Hendrik Budi. (2008). Corporate Social Responsibility (CSR). Jakarta: Sinar Grafika.

Zainuddin. (2019). Eksekusi Terhadap Pembatalan Surat Izin Mendirikan Bangunan Pada Perkara Tata Usaha Negara. De Lega Lata Jurnal Ilmu Hukum Fakultas Hukum Umsu. 4(2). 271288. Https://Doi.Org/10.30596/Dl1.V4i2.3198. 